\title{
"Application of an intangible asset valuation model using panel data for listed enterprises in Vietnam"
}

\begin{tabular}{|c|c|}
\hline \multirow[t]{2}{*}{ AUTHORS } & $\begin{array}{l}\text { Quan Minh Quoc Binh } \\
\text { Nguyen Minh Ha (D https://orcid.org/0000-0002-8411-7817 }\end{array}$ \\
\hline & Ngo Thi Huyen Trang \\
\hline ARTICLE INFO & $\begin{array}{l}\text { Quan Minh Quoc Binh, Nguyen Minh Ha and Ngo Thi Huyen Trang (2020). } \\
\text { Application of an intangible asset valuation model using panel data for listed } \\
\text { enterprises in Vietnam. Investment Management and Financial Innovations, } \\
\text { 17(1), 304-316. doi:10.21511/imfi.17(1).2020.26 }\end{array}$ \\
\hline DOI & http://dx.doi.org/10.21511/imfi.17(1).2020.26 \\
\hline RELEASED ON & Friday, 03 April 2020 \\
\hline RECEIVED ON & Thursday, 23 January 2020 \\
\hline ACCEPTED ON & Tuesday, 24 March 2020 \\
\hline LICENSE & $\begin{array}{l}(c)) E Y \\
\text { This work is licensed under a Creative Commons Attribution } 4.0 \text { International } \\
\text { License }\end{array}$ \\
\hline JOURNAL & "Investment Management and Financial Innovations" \\
\hline ISSN PRINT & $1810-4967$ \\
\hline ISSN ONLINE & $1812-9358$ \\
\hline PUBLISHER & LLC "Consulting Publishing Company "Business Perspectives" \\
\hline FOUNDER & LLC "Consulting Publishing Company "Business Perspectives" \\
\hline
\end{tabular}

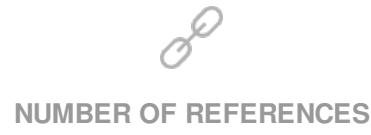

51

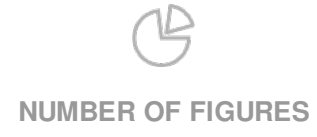

0

\section{Е=-}

NUMBER OF TABLES

7

C The author(s) 2023. This publication is an open access article. 


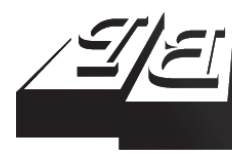

\section{BUSINESS PERSPECTIVES}

○

LLC "CPC "Business Perspectives"

Hryhorii Skovoroda lane, 10,

Sumy, 40022, Ukraine

www.businessperspectives.org
Received on: $23^{\text {rd }}$ of January, 2020 Accepted on: $24^{\text {th }}$ of March, 2020 Published on: $3^{\text {rd }}$ of April, 2020

(c) Quan Minh Quoc Binh, Nguyen Minh Ha, Ngo Thi Huyen Trang, 2020

Quan Minh Quoc Binh, Lecturer, Department of Economics and Public Management, Ho Chi Minh City Open University, Vietnam.

Nguyen Minh Ha, Associate Professor, President, Business and Economics Research Group, Ho Chi Minh City Open University, Vietnam. (Corresponding author)

Ngo Thi Huyen Trang, An Binh Commercial Joint Stock Bank, Vietnam.
Quan Minh Quoc Binh (Vietnam), Nguyen Minh Ha (Vietnam), Ngo Thi Huyen Trang (Vietnam)

\section{APPLICATION OF AN INTANGIBLE ASSET VALUATION MODEL USING PANEL DATA FOR LISTED ENTERPRISES IN VIETNAM}

\begin{abstract}
Intangible assets play an important role in increasing the value of companies. The performance of companies increasingly depends on ideas, information, and professional services rather than tangible assets. The question of how to accurately measure intangible assets remains a challenge for many scientists. This study aims to measure intangible assets of 396 companies listed on Vietnam's stock market between 2010 and 2014 using the panel data technique by Yamayuchi (2014). The estimation shows that intangible assets make up a large share of total assets of companies. In addition, construction, steel, building materials, mining, and food are sectors with high intangible assets in Vietnam. The study also finds a positive impact of intangible assets on improving company performance. The findings demonstrate the importance of investing in intangible assets, such as $\mathrm{R} \& \mathrm{D}$, technology, advertising, and human resources, to increase the value of a company in the future.
\end{abstract}

\section{Keywords}

$$
\text { intangible assets, panel data, valuation model, stock }
$$
price

\section{JEL Classification $\quad$ G31, M21, O30}

\section{INTRODUCTION}

Intangible assets are increasingly playing an important role for any company that wants to conduct production (Sveiby, 2010). Intangible assets are assets that do not have a specific physical form, such as a company's reputation, culture and value, brand name, technology, etc., but can make a significant contribution to creating business value (Osinski, Selig, Matos, \& Roman, 2017). As a result of recent mergers and acquisitions, foreign companies have acquired Vietnamese companies at a higher price than total tangible assets of these companies. For example, Pho 24 was purchased by Highlands Coffee for USD 20 million, and ICP was sold for more than USD 60 million for Marico. An important question that should be addressed is: Where does the source of a firm's intrinsic value come from? It is due to intangible assets. These assets are one of the key sources of comparative advantages for companies (Boujelben \& Fedhila, 2011). They also help companies to have better brand image and build customer loyalty (OECD, 2008). These assets widen the market value and increase the profit of a company (Jhunjhunwala \& Mishra, 2009; Bhatia \& Aggarwal, 2018). Although intangible assets are the primary source for the company performance, it is not easy to define and measure them. This is because these assets are not fully recorded in the balance sheets, and there is a lack of consistent data and definition. Previous studies show that researchers have not fully measured intangible assets. Bosworth and Rogers (1998) and Ehie and Olibe (2010) considered R\&D as intangible assets in their research. Kundu, Kulkarni, and NK (2010) used advertising intensity as a proxy 
for intangible assets. Therefore, there is a need to use a better methodology to fully measure every aspect of intangible assets. This paper employs a valuation model using panel data from Yamaguchi (2014) to quantify intangible assets of 396 companies listed on Vietnam's stock market from 2010 to 2014. In addition, the impact of intangible assets on firm's performance and stock prices is also examined.

The study contributes to the current literature on intangible assets in several ways. First, it employs a comprehensive measure for intangible assets, which is applied to test the relationship among intangible assets, firm performance and stock prices. The valuation model for intangible assets employs unobserved firm-specific effects based on a panel analysis to fully measure all aspects of intangible assets. Intangible assets have attracted a lot of public attention; their valuation is extremely crucial to provide information for researchers, managers, investors and creditors. Second, most of intangible asset studies concentrate on developed or industrialized countries, and there is very little research on emerging economies. As pointed out by Kamal (2011, p. 21), "specific research into emerging markets is necessary, since the unique characteristics of emerging economies may prove many of findings in developed economy settings invalid in an emerging economy setting". In this context, the paper is the first evidence on the role of intangible assets in firm performance in Vietnam - an emerging country with rapid economic growth rates in recent years. Third, the paper confirms the prediction of an efficient financial market theory and a resource-based theory in the context of an emerging economy. Finally, the research proposes the practical implications to managers and executives to make decisions in the competitive business arena.

The remainder of the paper is structured as follows. Section 1 provides a literature review of intangible assets. Section 2 describes data and the methodology, while Section 3 presents results. The last section concludes the paper.

\section{LITERATURE REVIEW}

\subsection{Definition of intangible assets}

There are many definitions of intangible assets due to different perceptions about them. The International Accounting Standard Board, Standard 38 (IAS 38), defines an intangible asset as "an identifiable non-monetary asset without physical substance. An asset is a resource that is controlled by the entity as a result of past events and from which future economic benefits are expected to flow to the entity" (IAS 38, 1997). According to this definition, computer software, patents, copyrights, licenses, motion picture films, customer lists, fishing licenses, and import quotas are considered as intangible assets. Goodwill that is obtained in a business combination is not recognized as intangible assets according to the IAS 38 scope. Goodwill that is generated internally belongs to the scope of IAS 38 but is not accounted as an asset, since it is not an identifiable resource. The costs of creating an intangible asset in a company are difficult to differentiate from the costs of maintaining or improving the entity's operations or goodwill. As a result, internally generated brands, mastheads are not considered as intangible assets. Research spend- ing is considered as an intangible asset. In addition, development spending that satisfies specified criteria is considered as the cost of an intangible asset. An intangible asset with a finite life will be amortized and it is subject to impairment testing. An intangible asset with an indefinite life will not be amortized, but it will be tested yearly for impairment. In addition, the IASB framework considers an intangible asset as future economic benefit gained by a particular entity due to transactions in the past. OECD (2011) states that "intangible assets are assets that do not have a physical or financial embodiment". OECD (2011) distinguishes the concepts of an "intangible asset" and an "intellectual asset". From their point of view, an intellectual asset is a part of an intangible asset. Intangible assets consist of three different parts, namely, innovative property, computerized information and economic competencies.

\subsection{Approaches to the assessment of intangible assets}

Traditionally, there are three approaches to measure intangible assets, including: (i) cost approach, (ii) income approach and (iii) market approach (see Reilly \& Schweis, 1999; Pastor, Glova, Liptak, 
\& Kovac, 2017; Osinski, Selig, Matos, \& Roman, 2017). Each valuation method has different strengths and weaknesses. The cost approach is relied on the total money that firms used to create intangible assets. This approach measures costs incurred in the past or costs to create similar assets. Employing costs in the past would bring many difficulties in calculating the depreciation. In addition, another problem of the cost approach is that it does not consider profits created by these assets (Yamayuchi, 2014). The income approach uses the methodology of discounted cash flow to evaluate intangible assets, which are based on income or expenditure data. This approach will discount the future benefits that are created with intangible assets to present value. One of the problems with this approach is that one cannot exactly estimate the future profits of firms. The market approach employs sales information of similar assets traded in the market. This approach is also considered as a "sales comparison" approach. The main problem with this approach is that it requires an active market, and assets are sold at fair prices.

\subsection{Panel data approach}

Panel data approach uses unobservable firm effects with panel analysis (Yamayuchi, 2014). Unobservable firm effects are explained as unobservable factors, such as technology innovation, employee motivation, management ability, and R\&D costs (Motohashi, 2005). The panel data approach of Yamaguchi (2014) is based on the idea of measuring the production function and developing the cost function with a duality approach to calculate equity of a firm. Next, the added value and costs are discounted to estimate intangible assets. The panel data model from Yamaguchi (2014) also combines the income approach. One of the advantages of the model is that it allows us to compute the profits resulting from intangible assets. In addition, the weakness of the market and cost approaches is solved.

Lev and Radhakrishnan (2003) developed a production function to interpret firms' sales growth based on rising production inputs. Capital, labor, $\mathrm{R} \& \mathrm{D}$ and total factor productivity are included in the regression function with panel analysis. Ramirez and Hachiya (2006) also defined a regression model with panel analysis to interpret sales growth and the market value of equity with inputs such as R\&D and general administrative expenses. In the research of total factor productivity as an impact of an organization capital, Sadowski and Ludewig (2003) use a similar method for panel analysis to assess the production function with firm value added as a dependent variable. Production factors, such as capital, labor, human capital, and social capital, are included as independent variables. The added value that can be obtained from organization capital is discounted with the risk-free rate to determine the asset value. Yamaguchi (2014) also uses the panel data analysis with fixed effect as effects of intangible assets, but Yamaguchi's (2014) valuation method differs from previous studies in calculating corporate asset values by discounting costs and obtaining value added from intangible assets.

\subsection{Theoretical framework}

This paper is based on two important theories that are relevant to the effect of intangible assets on a firm's value added, profits and stock prices. These theories are an Efficient Market Hypothesis Theory and a Resource Based Theory.

\subsubsection{Efficient Market Hypothesis}

According to the theory of efficient financial markets, stock prices reflect all available information of the stock, and price valuation varies if investors have new data about the expected future cash flow of a company (Malkiel \& Fama, 1970). The efficient market would provide accurate signals for resource allocation, as market prices are a representative of each stock intrinsic worth. Malkiel and Fama (1970) classified market efficiency into three forms: (i) weak form, which is based on information on historical data, (ii) semi-strong form is based on the information of public data, and (iii) strong from is based on private information (or insider information). Since the information on intangible assets is not reported in public financial statements, all intangible assets internally generated are considered as private information. Specifically, intangible assets are reflected in the financial statements of a firm only if they are acquired assets and assets with identifiable value and useful lifespan, which is, therefore, can be amortized. Internally developed intangible assets 
are not registered in the financial statements. This is because these assets were developed internally and have no price. The theory of an efficient market hypothesis is relevant for this study, since it helps to explain that the increase in stock prices is a result of the growth of intangible assets. This discussion leads to the first hypothesis:

\section{H1: Firms with higher intangible assets have higher stock prices.}

\subsubsection{Resource-based theory}

According to the resource-based theory, intangible assets are considered a key factor explaining the sustainability of companies (Villalonga, 2004). The theory provides an explanation of the competitive advantage of firms in 1980s and 1990s thanks to major publications by Wernerfelt (1984), Porter (1991), Grant (1991), and Barney and Clark (2007). The scholars supporting this theory suggest that we should look inside the firms to explore their sources of competitive advantage. Itami $(1987$, p. 1) pointed out that "intangible assets, such as a particular technology, accumulated consumer information, brand name, reputation and corporate culture, are invaluable to the firm's competitive power. In fact, these invisible assets are often the only real source of competitive edge that can be sustained over time". The theory also predicts the role of intangible assets in achieving better firm performance by saying "the more intangible resources a firm has, the greater the sustainability of its competitive advantage" (Itami, 1987, p. 1). Lev and Sougiannis (1996) state that R\&D investments will enhance firm's profits in the future. This theory is relevant to the current study because it suggests that firms with higher intangible assets will achieve higher profitability and firm value. This discussion leads to the second and third hypotheses:

\section{H2: Firms with higher intangible assets have higher profitability.}

H3: Firms with higher intangible assets have higher value added.

\subsection{Previous empirical studies}

For decades, scholars have been examining the impact of intangible assets on firm performance. However, the relationship between intangible assets and firm performance is still ambiguous. Some authors have found a positive influence of intangible assets on firm performance (Bhatia \& Aggarwal, 2018; Kim, Park, Lee, \& Kim, 2018; Gupta, Banerjee, \& Onur, 2017; Kamasak, 2017), while some others have reported negative associations (Widiantoro, 2012; Ruiwen \& Honghui, 2010). Gupta et al. (2017) find a positive association between R\&D investment (a proxy for an intangible asset) and firm value. Duqui and Torluccio (2011) examine the relationship between $\mathrm{R} \& \mathrm{D}$ spending and the market value of European listed companies in 2001-2007. They find a positive influence of $\mathrm{R} \& \mathrm{D}$ on firm market value. Ifeanyi and Caroline (2016) report a negative impact of intangible assets on economic value added of selected manufacturing firms in Nigeria. Using a sample of 243 Turkish firms, Kamasak (2017) investigates the contribution of tangible and intangible resources, as well as capabilities, on firm performance. The author finds that intangible resources contribute more to firm performance than tangible resource.

In addition, most of studies on intangible assets were conducted in developed (Ehie \& Olibe, 2010; Wang, 2011; Su \& Wells, 2015; Vithessonthi \& Racela, 2016) or industrialized countries (Nagaoka, 2006; Min \& Smyth, 2016; T. C. Chen, Guo, H. M. Chen, \& Wei, 2019), while very little research was made in emerging markets. Recently, most of research on intangible assets in emerging countries comes from China (Rao, Yu, \& Cao, 2013; Kim et al., 2018) and India (Pal \& Soriya, 2012; Bhatia \& Aggarwal, 2018). For more than three decades, Vietnam has been considered as a rising economic star in the Asia-Pacific region based on economic innovation and open-door policy. For instance, economic growth rates continuously reached more than 6 per cent per year during the past 30 years. This indicated that Vietnam's economic growth rate remains strong despite the risks to global economy. Furthermore, economic growth rates in Vietnam amounted to 7.02 per cent in 2019, which corresponds to the economic growth rate of leading countries of the world. Therefore, a study on the effect of intangible assets in the context of Vietnam would be very interesting to examine.

The evaluation of extant literature also shows that intangible assets have been explored by researchers only in parts or fragments. Many scholars 
use $\mathrm{R} \& \mathrm{D}$ investment as a proxy for intangible assets (Ehie \& Olibe, 2010; Duqi \& Torluccio, 2011), while others employ advertising intensity as intangible (Shah, Mirza, \& Abbas, 2011). Some scholars consider balance sheet intangible assets as intangible assets (Darabi \& Vojohi, 2013), and other researchers simply calculate intangible assets as the difference between market value of equity and book value of equity (Salamudin, Bakar, Ibrahim, \& Hassan, 2010). Therefore, we need a comprehensive method for intangible assets valuation that captures every aspect of intangible assets. In Vietnam, the research gap is even wider. Therefore, this paper is designed to fill the research gap by using the panel data approach from Yamayuchi (2014) to measure intangible assets and then examine their impact on firm performance.

\section{DATA AND METHODOLOGY}

\subsection{Model description}

To evaluate intangible assets based on Yamaguchi's method, this study starts with the Cobb-Douglas (1928) production function:

$$
Q_{i t}=\alpha_{i} K_{i t}^{\alpha} L_{i t}^{\beta} e_{i t}^{\varepsilon Q}
$$

where $Q_{i t}$ is the value added of firm $i$ in year $t$, $K_{i t}$ represents capital of firm $i$ in year $t, L_{i t}$ stands for labor of firm $i$ in year $t$, and $\alpha, \beta$ are parameters that represent the contributions of capital and labor to added value.

Parameter $a_{i}$ in equation (1) describes the impact of technology (or total factor productivity) on value added $\mathrm{Q}$ rather than other production factors. The factors include know-how, motivation of workers and sale power (Yamaguchi, 2014). In general, $a_{i}$ is the impact of intangible assets on growth rates of firms. The impacts of intangible assets $a_{i}$ can be divided into company-specific effects $A_{i}$ and growth rate $\lambda$ of industry $h$ in time $t$.

$$
\alpha_{i}=A_{i} e^{\sum_{h}^{M} \lambda_{h} D_{h(i) t}}
$$

where $\lambda_{h}$ represents the growth rate $\lambda$ of industry $h, D_{h}(i)$ is the dummy of firm $i$ in industry $h$.
We have

$$
D_{h}(i)=\left\{\begin{array}{ll}
1 & i \in V_{h} \\
0 & i \neq V_{h}
\end{array} .\right.
$$

Replace equation (2) with equation (1):

$$
Q_{i t}=A_{i} e^{\sum_{h}^{M} \lambda_{h} D_{h(i) t}} K_{i t}^{\alpha} L_{i t}^{\beta} e^{\varepsilon_{i t}^{O}}
$$

To estimate $\alpha, \beta$ from equation (3), the logarithm of equation (3) is used:

$$
\begin{aligned}
& \ln Q_{i t}=\ln A_{i}+\sum_{h}^{M} \lambda_{h} D_{h}(i) t+ \\
& +\alpha \ln K_{i t}+\beta \ln L_{i t}+\varepsilon_{i t}^{Q} .
\end{aligned}
$$

According to Yamaguchi (2014), the value added of $i^{\text {th }}$ companies can be obtained from the financial statement with the following formula:

$$
p_{t} Q_{i t}=\text { Operating profit }+
$$

+ Depreciation + Personnel expenses,

where $p_{t}$ is the deflator of year $t$.

Equation (4) is regressed to obtain the values of $\alpha$ and $\beta$. However, there is no value of $A_{i}$. it is necessary to take the differential of equation (4):

$$
\begin{aligned}
& d\left(\ln Q_{i t}\right)=\sum_{h}^{M} \lambda_{h} D_{h}(i) t+ \\
& +\alpha d\left(\ln K_{i t}\right)+\beta d\left(\ln L_{i t}\right)+d\left(\varepsilon_{i t}^{Q}\right),
\end{aligned}
$$

where $d(\ldots)$ is the difference form of variables.

The profit $\pi$ function has the following formula:

$$
\begin{aligned}
& \pi=\text { Operating Profit- } \\
& \text {-Interest rate-Tax. }
\end{aligned}
$$

From equations (5) and (7):

$$
\begin{aligned}
& \pi=p_{t} Q_{i t}-\text { Depreciation cost }- \\
& \text { Personnel Expense-Interest - Tax. }
\end{aligned}
$$

It is assumed that $C_{i t}$ is the total cost of firm $i$ in year $t$, excluding cost of goods sold: 


\section{$C_{i t}=$ Depreciation cost +}

+ Personnel expense + Interest + Tax.

The profit of firm $i^{\text {th }}$ in year $t$ can be computed:

$$
\pi_{i t}=p_{t} Q_{i t}-C_{i t} \text {. }
$$

The cost function based on duality approach can be identified. Duality approach is a basic concept of microeconomics to specify cost function and production function. This concept has been discussed by Samuelson (1947), Fuss and McFadden (1978). According to the duality approach, firms can produce products by combining production factors to minimize costs. To make his model simpler, Yamaguchi (2014) replaced $\beta$ with $1-\alpha$, and he assumed that firms had constant returns to scale. This paper does not assume a type of economy of scale at the beginning. Therefore, the cost function is different from that of Yamaguchi (2014):

$$
\begin{aligned}
& C_{i t}=\left[A_{i} e^{\sum_{h}^{M} \lambda_{h} D_{h(i) t}}\right]^{-\frac{1}{\alpha+\beta}} \times \\
& \times\left(\frac{\alpha^{\frac{\beta}{\alpha+\beta}}}{\beta}+\frac{\beta^{\frac{\alpha}{\alpha+\beta}}}{\alpha}\right) R_{i t}^{\frac{\alpha}{\alpha+\beta}} W_{i t}^{\frac{\beta}{\alpha+\beta}} Q_{i t}^{\frac{1}{\alpha+\beta}} e^{\varepsilon_{i t}^{C}},
\end{aligned}
$$

where $R_{i t}$ stands for nominal cost of capital of company $i^{\text {th }}$ in year $t, W_{i t}$ represents nominal wage of company $i^{\text {th }}$ in year $t$.

The cost function can be estimated by equation (11). $Q_{i t}, \alpha$, and $\beta$ can be collected by equation (6).

$$
\begin{aligned}
& \hat{C}_{i t}=\left(\frac{\hat{\alpha} \frac{\hat{\beta}}{\hat{\alpha}+\hat{\beta}}}{\hat{\beta}}+\frac{\hat{\beta} \frac{\hat{\alpha}}{\hat{\alpha}+\hat{\beta}}}{\hat{\alpha}}\right) \times \\
& \times\left(\hat{\alpha}_{i} \hat{\alpha}^{\hat{\alpha}} \hat{\beta}^{\hat{\beta}}\right)^{-\frac{1}{\hat{\alpha}+\hat{\beta}}} R_{i t}^{\frac{\hat{\alpha}}{\hat{\alpha}+\hat{\beta}}} W_{i t}^{\frac{\hat{\beta}}{\hat{\alpha}+\hat{\beta}}} \hat{Q}_{i t}^{\frac{1}{\hat{\alpha}+\hat{\beta}}} .
\end{aligned}
$$

The value of the nominal equity $E$, which has an effect of intangible assets on company $i$ in period $t$, can be computed as the present value of value added of a company and the cost of a company.

$$
E_{i t}=\frac{p_{t} Q_{i t} e^{\lambda h}}{r_{i}-\lambda_{h}}-\frac{C_{i t}}{r_{i}}
$$

In formula (13), $p_{t}$ is the deflator for year $t, r_{i}$ represents the cost of equity of company $i, E_{i t}$ contains both the value of intangible and tangible assets. To calculate the value of intangible assets, the value of $E_{i t}$ is taken minus the value of tangible assets. Equity value that does not include intangible assets $E_{i t}^{\text {nonI }}$ can be computed by the following formula:

$$
\begin{aligned}
& E_{i t}^{n o n I}=\frac{p_{i} K_{i t}^{\alpha} L_{i t}^{\beta}}{r_{i}}- \\
& -\frac{(\alpha \beta)\left(R_{i t}^{n o n I}\right)^{\alpha}\left(W_{i t}^{n o n I}\right)^{\beta} K_{i t}^{\alpha} L_{i t}^{\beta}}{r_{i}},
\end{aligned}
$$

where $R_{i t}^{\text {nonI }}$ and $W_{i t}^{\text {nonI }}$ can be calculated with the formula (see Yamaguchi, 2014):

$$
\begin{aligned}
& R_{i t}^{\text {nonI }}=R_{i t} \frac{p_{i} K_{i t}^{\alpha} L_{i t}^{\beta}}{r_{i}} \frac{r_{i}-\lambda_{h}}{p_{t} Q_{i t} e^{\lambda_{h}}}, \\
& W_{i t}^{n o n I}=W_{i t} \frac{p_{i} K_{i t}^{\alpha} L_{i t}^{\beta}}{r_{i}} \frac{r_{i}-\lambda_{h}}{p_{t} Q_{i t} e^{\lambda^{h}}},
\end{aligned}
$$

where $R_{i t}^{\text {nonI }}$ represents the nominal cost of capital without intangible assets, and $W_{i t}^{\text {nonI }}$ represents nominal wage of labor without intangible assets.

The intangible asset's value from equations and (14) can be computed:

$$
I_{i t}=E_{i t}-E_{i t^{n o n I}}
$$

\subsection{Data sources}

This study uses the Vietnam Enterprises Survey Data from the General Statistics Office for the period 2010-2014. The reason for using 2010-2014 data for this paper is that it is the period during which Vietnam was not affected much by the 2008 global economic crisis. In addition, 2014 is the latest data that could be collected from the General Statistics Office of Vietnam. There are 396 listed companies on Vietnam's stock market. In addi- 
Table 1. Description of variables used in the model

Source: Authors' summary.

\begin{tabular}{|c|c|c|c|}
\hline No. & Data & Variable symbol & Source \\
\hline 1 & Value added of a company & $Q_{\text {jt... }}$ & Obtained from equation (5) \\
\hline 2 & Operating profit & OPE & Vietnam Enterprise Survey \\
\hline 3 & Personnel expense & $P E$ & Vietnam Enterprise Survey \\
\hline 4 & Interest & Interest & Vietnam Enterprise Survey \\
\hline 5 & $\operatorname{Tax}$ & Tax & Vietnam Enterprise Survey \\
\hline 6 & Total capital & $\mathrm{K}_{\mathrm{it} . .}$ & Vietnam Enterprise Survey \\
\hline 7 & Total labor & $\mathrm{L}_{\text {it } . .}$ & Vietnam Enterprise Survey \\
\hline 8 & Cost of equity & $r_{i t}$ & Computed from CAPM \\
\hline 9 & Wage & $W_{\text {it... }}$ & Vietnam Enterprise Survey \\
\hline 10 & Tangible assets of a company & $T_{i t}$ & Vietnam Enterprise Survey \\
\hline 11 & Intangible assets of a company & $\mathrm{I}_{\text {it... }}$ & Authors' calculation \\
\hline 12 & Deflator & $P_{t}$ & CPI from GSO \\
\hline
\end{tabular}

tion, stock prices are taken from http://www.cophieu68.vn/. Stock prices are collected by day and summed up to year average to measure the impact of intangible assets on stock prices.

The nominal cost of capital $R$ can be computed by using the Capital Asset Pricing Model. Firstly, it is necessary to calculate the cost of equity $r$ before estimating $R$. given the CAPM model, the following formula can be obtained:

$$
r=r_{f}+\text { beta } \cdot\left(r_{m}-r_{f}\right)
$$

where $r$ represents cost of capital of firms, $r_{f}$ stands for the risk free rate. Long-term treasury bonds to proxy for risk-free asset are used; $r_{m}$ is the market rate.

\section{RESULTS AND ANALYSIS}

\subsection{First estimation: Compute $\alpha$ and $\beta$}

Equation (6) is employed to estimate $\alpha$ and $\beta$. The data on companies will be classified by sectors based on the industry division of the General Statistics Office. There are 47 industries, and 46 dummy variables are created for the regres- sion model. Panel data regression with fixed and random effect models is used. Hausman test shows that the random effect model is more appropriate that the fixed effect model. An industry dummy is also included to examine the effect of the industry growth rates on company performance. The "robust" command in Stata is used to eliminate the problem of heteroskedasticity. In addition, the VIF value is smaller than 10. It means that there is no multicollinearity in the model.

The regression results of equation (6) show that coefficients $\alpha$ and $\beta$ are similar in three regression equations. The regression results of the random effects model with the dummy variable of the industry show that the sum of coefficients $\alpha$ and $\beta$ equals 1. It means that Vietnamese listed enterprises have constant returns to scale. It means that when firms double their capital and labor, operating profit turnover will double.

\subsection{Estimation of intangible assets}

Table 3 presents the results for top 10 industries with highest intangible assets, including construction, steel and steel products, mining, and food, while Table 4 provides top 10 firms in Vietnam by intangible asset value.

Table 2. Regression results of equation (6) by using fixed and random effect models

Source: Authors' estimation.

\begin{tabular}{c|l|c|c|c}
\hline No. & Model & $\boldsymbol{\alpha}$ & $\boldsymbol{\beta}$ & $\boldsymbol{R}^{\mathbf{2}}$ \\
\hline 1 & Fixed effects model without industrial dummy variables & 0.52 & 0.48 & 0.54 \\
2 & Random effects model without industrial dummy & 0.52 & 0.48 \\
3 & Random effects model with industrial dummy variables & 0.55 & 0.54 & 0.45 \\
\hline
\end{tabular}


Table 3. Top 10 industries in Vietnam with highest intangible assets in 2014

Source: Authors' estimation.

\begin{tabular}{|c|c|c|}
\hline No. & Industry & Intangible assets (VND million) \\
\hline 1 & Construction & $2,828,621,432$ \\
\hline 2 & Steel and steel products & $1,408,252,941$ \\
\hline 3 & Construction Materials \& Furniture & $433,417,450$ \\
\hline 4 & Mining & $313,367,282$ \\
\hline 5 & Food & $248,501,145$ \\
\hline 6 & Garment & $173,770,528$ \\
\hline 7 & Personal Facility & $168,848,562$ \\
\hline 8 & Biological Technology & $154,272,789$ \\
\hline 9 & Power manufacturing and distribution & $138,230,313$ \\
\hline 10 & Tire production & $126,117,752$ \\
\hline
\end{tabular}

Table 4. Top 10 Vietnamese firms by intangible asset value, 2014

Source: Author's estimation.

\begin{tabular}{|c|c|c|c|}
\hline $\begin{array}{l}\text { Stock } \\
\text { code }\end{array}$ & Company name & Industry & Intangible assets (VND million) \\
\hline LM8 & Lilama 18 joint stock company & Construction & $1,109,328,422$ \\
\hline DTL & Đại Thiên Lộc joint stock company & Steel and steel products & $459,174,377$ \\
\hline CTD & Coteccons construction joint stock company & Construction & $313,106,026$ \\
\hline HSG & Hoa Sen group joint stock company & Steel and steel products & $240,150,048$ \\
\hline POM & Pomina steel joint stock company & Steel and steel products & $193,553,220$ \\
\hline $\mathrm{MHL}$ & Minh Hữu Liên joint stock company & Steel and steel products & $173,657,627$ \\
\hline LM7 & Lilama 7 joint stock company & Construction & $167,196,011$ \\
\hline SMC & SMC trading investment joint stock company & Steel and steel products & $160,434,262$ \\
\hline PNJ & Phu Nhuan jewelry joint stock company & Personal Facility & $128,836,027$ \\
\hline VNM & Vietnam dairy products joint stock company & Food & $117,690,263$ \\
\hline
\end{tabular}

\subsection{Assessment of the impact of intangible assets on firm performance}

The impact of intangible assets on value added of firm, EBIT (earnings before interest and taxes) and stock price is examined. In the authors' regression models, tangible assets, intangible assets and industry growth rates (lamda) are added as independent variables.
The regression results from Table 5 with the random effects model show that intangible assets have a positive and statistically significant impact on firm value added. Therefore, $\mathrm{H} 3$ is accepted at the $1 \%$ level of significance. When the value of intangible assets increases by $1 \%$, the added value of a company will increase by $0.92 \%$. The finding supports the Resource Based Theory that states that intangible assets are considered as key factor that explains firms' sustainability. These findings

Table 5. The impact of intangible assets on a firm's value added

Source: Authors' estimation.

\begin{tabular}{|c|c|c|c|}
\hline Value added & Model 1 & Model 2 & Model 3 \\
\hline \multirow{2}{*}{ C } & 0.20 & $-2.84^{*}$ & $-3.01^{*}$ \\
\hline & $(0.194)$ & $(0.28)$ & $(0.29)$ \\
\hline \multirow{2}{*}{ Intangible asset } & $0.86^{*}$ & $0.93^{*}$ & $0.92 *$ \\
\hline & $(0.011)$ & $(0.011)$ & $(0.01)$ \\
\hline \multirow{2}{*}{ Tangible asset } & - & - & $0.02 *$ \\
\hline & - & - & $(0.006)$ \\
\hline \multirow{2}{*}{ Lamda } & - & $-0.4^{*}$ & $-0.4^{*}$ \\
\hline & - & $(0.04)$ & $(0.04)$ \\
\hline Obs & 1228 & 505 & 504 \\
\hline Adjusted $R^{2}$ & 0.69 & 0.76 & 0.77 \\
\hline
\end{tabular}

Note: $*$ shows the $1 \%$ level of significance, ${ }^{* *}$ shows the $5 \%$ level of significance, and $* * *$ shows the $10 \%$ level of significance. 
Table 6. The impact of intangible assets on EBIT

Source: Authors' estimation.

\begin{tabular}{|c|c|c|c|}
\hline EBIT & Model 1 & Model 2 & Model 3 \\
\hline \multirow{2}{*}{ C } & $-1.88 *$ & $-3.68^{*}$ & $-7.17^{*}$ \\
\hline & $(0.48)$ & $(0.69)$ & $(0.81)$ \\
\hline \multirow{2}{*}{ Intangible assets } & $0.93^{*}$ & $1.08^{*}$ & $1.03^{*}$ \\
\hline & $(0.03)$ & $(0.042)$ & $(0.05)$ \\
\hline \multirow{2}{*}{ Tangible assets } & - & - & 0.11 \\
\hline & - & - & $(0.07)$ \\
\hline \multirow{2}{*}{ Lamda } & - & $-0.53^{*}$ & $-0.52 *$ \\
\hline & - & $(0.05)$ & $(0.05)$ \\
\hline Observations & 1209 & 495 & 494 \\
\hline Adjusted $R^{2}$ & 0.57 & 0.65 & 0.67 \\
\hline
\end{tabular}

Note: $*$ shows the $1 \%$ level of significance, ${ }^{* *}$ shows the $5 \%$ level of significance, ${ }^{* *}$ shows the $10 \%$ level of significance.

Table 7. The impact of intangible assets on stock prices

Source: Authors' estimation.

\begin{tabular}{|c|c|c|c|}
\hline Stock prices & Model 1 & Model 2 & Model 3 \\
\hline \multirow{2}{*}{ C } & $-6.47 * * *$ & $-20.2^{* *}$ & $-34.63^{*}$ \\
\hline & $(3.74)$ & $(8.85)$ & $(11.63)$ \\
\hline \multirow{2}{*}{ Intangible assets } & $1.43^{*}$ & $1.16^{*}$ & $0.80 * *$ \\
\hline & $(0.26)$ & $(0.42)$ & $(0.37)$ \\
\hline \multirow{2}{*}{ Tangible assets } & - & - & $1.70 *$ \\
\hline & - & - & $(0.61)$ \\
\hline \multirow{2}{*}{ Lamda } & - & $-5.42 *$ & $-5.55^{*}$ \\
\hline & - & $(1.24)$ & (1.19) \\
\hline Observations & 1190 & 505 & 504 \\
\hline Adjusted $R^{2}$ & 0.02 & 0.1888 & 0.2257 \\
\hline
\end{tabular}

Note: ${ }^{*}$ shows the $1 \%$ level of significance, ${ }^{* *}$ shows the $5 \%$ level of significance, ${ }^{* * *}$ shows the $10 \%$ level of significance.

are new in the context of emerging economies, but are consistent with the previous research findings in the developed economies (Bae \& Kim, 2003; Ehie \& Olibe, 2010). It is important to note that intangible assets have a greater contribution to the value of a company than tangible assets. The finding is consistent with Kamasak (2017) who investigates the contribution of tangible and intangible resources and capabilities to Turkish firms' performance. The authors find that intangible resource contributes more to firm performance than tangible resource.

The regression results from Table 6 show that only intangible assets have a positive and statistically significant impact on earnings before interest and taxes (EBIT). Specifically, if the value of intangible assets increases by $1 \%$, EBIT of firms will increase by $1.03 \%$. Therefore, $\mathrm{H} 2$ is accepted at the $1 \%$ level of significance. One can see that intangible assets play an important role in increasing the profits of companies. Intangible assets provide firms with competitive advantages and help them to achieve future profitability. The finding is similar to that obtained by Bhatia, Khushboo Aggarwal (2018). In addition, this result is similar to the research of Ocean Tomo Consulting Company ${ }^{1}$, which concluded that intangible assets currently account for more than $80 \%$ of the market value of $S \& P$ 500 companies. Similarly, a study by McKinsey Group showed that intangible assets helped firms increase profits by $31 \%$ compared to firms without intangible assets. This is evident in supporting Resource Based Theory in the context of emerging markets.

Table 7 presents the results of the impacts of tangible and intangible assets on company's stock price. In fact, there are many factors that can affect the stock price of a company, includ-

1 The information is collected from http://blog.trginternational.com 
ing micro and macro factors. The macro factors that have an impact on stock prices are gold prices, interest rates, inflation rates, exchange rates, money supply, and gross domestic product (Maysami \& Koh, 2000). The micro factors include capital structure, ROA, ROE, etc. However, there is no study examining the impact of intangible assets on companies' stock prices. The results of the panel data regression with random effects show that intangible assets have a positive impact on the company's stock value. Therefore, H1 is supported. The evidence support the Efficient Market Hypothesis. In addition, the results are similar to Banker (2019). However, the contribution of tangible assets is greater than that of intangible assets. Specifically, when tangible assets increase by $1 \%$, the share price increases by $1.7 \%$; meanwhile, a $1 \%$ increase in intangible assets only contributes to a $0.8 \%$ increase in stock prices.

\section{CONCLUSION}

It is well-documented that intangible assets play an important role in enhancing firm performance. The performance of companies increasingly depends on ideas, information, professional services rather than tangible assets. However, the empirical question of how to conduct an accurate measurement of intangible assets remains a challenge for many scholars. Previous studies show that intangible assets are not fully measured. Many scholars use R\&D investment as a proxy for intangible assets (Bosworth \& Rogers, 1998; Ehie \& Olibe, 2010), while others employ advertising intensity as intangible (Kundu et al., 2010). Therefore, there is a need to use a better methodology to fully measure every aspect of intangible assets. The paper measures intangible assets of 396 enterprises listed on Vietnam's stock market by using the panel data method from Yamayuchi (2014) in the period of 2010 2014. The production function is first estimated and then the cost function of firms is constructed. In the next step, the study computes the value of company's equity and the equity of a company with tangible assets. The value of intangible assets is calculated by subtracting the value of equity of the total assets to equity value of firms without intangible assets. The results show that construction, steel, building materials, mining, and food are the industries with high intangible asset value in Vietnam. The positive impact of intangible assets on enhancing firm performance is also found.

This study extends the intangible assets literature in several ways. First, it provides new evidence on the impact of intangible assets on firm performance in the context of Vietnam, an emerging market with rapid economic growth rates. Second, the results confirm the theoretical prediction in the context of an emerging market. According to the efficient financial markets theory, stock prices reflect all available information on the stock, and price valuation varies if investors have new information on the companies' expected future cash flows. The evidence from Vietnamese firms suggests that an increase in stock prices of listed companies is a result of an increase in intangible assets. The findings also confirm the prediction of resource-based theory, which states that intangible assets are considered a key factor that explains firm sustainable performance of. Third, the research finding implies that managers of companies should take into account the importance of intangible assets for improving firm performance. Therefore, they should invest more in R\&D activities, technology, advertising, brand name, reputation and human resources to enhance the value of a firm in the future.

The paper has some limitations. First, the problem of an omitted variable may arise in this study. Due to the data availability, the study only includes tangible assets, intangible assets and industry growth rates as independent variables. Future research should consider other variables that represent firm characteristics, such as firm age and firm size, which may affect firm performance. Second, the study period is limited from 2010 to 2014. Therefore, further research in Vietnam should extend the study period to examine the relationship between intangible assets and firm performance. 


\section{AUTHOR CONTRIBUTIONS}

Conceptualization: Nguyen Minh Ha, Quan Minh Quoc Binh, Ngo Thi Huyen Trang.

Data curation: Quan Minh Quoc Binh, Ngo Thi Huyen Trang.

Formal analysis: Nguyen Minh Ha, Quan Minh Quoc Binh, Ngo Thi Huyen Trang.

Investigation: Nguyen Minh Ha, Quan Minh Quoc Binh.

Methodology: Nguyen Minh Ha, Quan Minh Quoc Binh.

Project administration: Nguyen Minh Ha.

Resources: Nguyen Minh Ha, Quan Minh Quoc Binh.

Supervision: Nguyen Minh Ha.

Validation: Nguyen Minh Ha, Quan Minh Quoc Binh, Ngo Thi Huyen Trang.

Visualization: Nguyen Minh Ha, Quan Minh Quoc Binh, Ngo Thi Huyen Trang.

Writing - original draft: Quan Minh Quoc Binh, Ngo Thi Huyen Trang.

Writing - review \& editing: Nguyen Minh Ha, Quan Minh Quoc Binh.

\section{REFERENCES}

1. Bae, S. C., \& Kim, D. (2003). The effect of R\&D investments on market value of firms: Evidence from the US, Germany, and Japan. Multinational Business Review. Retrieved from https:// www.questia.com/library/ journal/1P3-635858601/theeffect-of-r-d-investments-onmarket-value-of-firms

2. Banker, R. D., Huang, R. Natarajan, R., \& Zhao, S. (2019) Market Valuation of Intangible Asset: Evidence on SG\&A Expenditure. The Accounting Review, 94(6), 61-90. https://doi. org/10.2308/accr-52468

3. Barney, J. B., \& Clark, D. N. (2007). Resource-based theory: Creating and sustaining competitive advantage. Oxford University Press on Demand.

4. Bhatia, A., \& Aggarwal, K. (2018). Impact of investment in intangible assets on corporate performance in India. International Journal of Law and Management. https://doi. org/10.1108/IJLMA-05-2017-0127

5. Bosworth, D., \& Rogers, M. (1998). Research and development, Intangible Assets and the performance of Large Australian Companies. Melbourne Institute of Applied Economic and Social Research.

6. Boujelben, S., \& Fedhila, H. (2011). The effects of intangible investments on future OCF.
Journal of Intellectual Capital, 12(4), 480-494. https://doi. org/10.1108/14691931111181689

7. Chen, T. C., Guo, D. Q., Chen, H. M., \& Wei, T. T. (2019). Effects of R\&D intensity on firm performance in Taiwan's semiconductor industry. Economic research-Ekonomska istraživanja, 32(1), 2377-2392. https://doi.org/1 0.1080/1331677X.2019.1642776

8. Cobb, W., \& Douglas, P. H. (1928). A theory of production. The American Economic Review, 18(1), 139-165.

9. Darabi, R., \& Vojohi, V. (2013). The survey of the conservative relationship between the intangible assets and management performance ratio. International Journal of Innovation and Applied Studies, 3(3), 749-757. Retrieved from http://paper.researchbib. com/view/paper/6096

10. Duqi, A., \& Torluccio, G. (2011). Can R\&D expenditures affect firm market value? An empirical analysis of a panel of European listed firms. In Bank Performance, Risk and Firm Financing (pp. 215-241). Palgrave Macmillan, London. https://doi. org/10.1057/9780230313873_11;

11. Ehie, I. C., \& Olibe, K. (2010). The effect of R\&D investment on firm value: An examination of US manufacturing and service industries. International Journal of Production Economics, 128(1), 127-135. https://doi.org/10.1016/j. ijpe.2010.06.005

12. Fuss, M. A., \& McFadden, D. (1978). Production economics: A dual approach to theory and applications. Amsterdam: NorthHolland.

13. Grant, R. M. (1991). The resourcebased theory of competitive advantage: implications for strategy formulation. California Management Review, 33(3), 114135. https://doi.org/10.1016/B9780-7506-7088-3.50004-8

14. Gupta, K., Banerjee, R., \& Onur, I. (2017). The effects of $\mathrm{R} \& \mathrm{D}$ and competition on firm value: International evidence. International Review of Economics \& Finance, 51, 391-404. https://doi. org/10.1016/j.iref.2017.07.003

15. IAS 38 Basis for Conclusion. (1997). Exposure draft 60, Intangible Assets, International Accounting Standards Committee.

16. Ifeanyi, N., \& Caroline, O. (2016). Evaluating the Effect of Intangible Assets on Economic Value added of Selected Manufacturing Firms in Nigeria. European Journal of Business and Management, 8, 15. Retrieved from https://iiste.org/ Journals/index.php/EJBM/article/ view/30885

17. Itami, H., (1987). Mobilizing Invisible Assets. Harvard University Press, Cambridge, MA. 
18. Jhunjhunwala, S., \& Mishra, R. K. (2009). Corporate governance and corporate performance. International Journal of Business Research, 9(2), 62-67. https://doi. org/10.1016/j.jcorpfin.2008.03.006

19. Kamal, S. (2011). Entry mode and subsidiary performance in emerging economies. Mustang Journal of Business and Ethics, 2(1), 20-29. Retrieved from https://core. ac.uk/download/pdf/61802088. pdf

20. Kamasak, R. (2017). The contribution of tangible and intangible resources, and capabilities to a firm's profitability and market performance. European Journal of Management and Business Economics. https://doi.org/10.1108/ EJMBE-07-2017-015

21. Kim, W. S., Park, K., Lee, S. H., \& Kim, H. (2018). R\&D Investments and Firm Value: Evidence from China. Sustainability, 10(11), 4133. https://doi.org/10.3390/ su10114133

22. Kundu, A., Kulkarni, P., \& NK, A. M. (2010). Advertising and firm value: mapping the relationship between advertising, profitability and business strategy in India. Changing Ideas in Strategy (Ed. Arun Sinha), Narosa Publishing.

23. Lev, B., \& Radhakrishnan, S. (2003). The measurement of firm-specific organization capital (No. w9581). National Bureau of Economic Research. https://doi. org/10.3386/w9581

24. Lev, B., \& Sougiannis, T. (1996). The capitalization, amortization, and value-relevance of $\mathrm{R} \& \mathrm{D}$. Journal of Accounting and Economics, 21(1), 107-138. https://doi.org/10.1016/01654101(95)00410-6

25. Malkiel, B. G., \& Fama, E. F. (1970). Efficient capital markets: A review of theory and empirical work. The Journal of Finance, 25(2), 383-417. https://doi. org/10.1111/j.1540-6261.1970 tb00518.x

26. Maysami, R. C., \& Koh, T. S. (2000). A vector error correction model of the Singapore stock market. International Review of Economics \& Finance, 9(1), 79-96. https://doi.org/10.1016/S10590560(99)00042-8

27. Min, B. S., \& Smyth, R. (2016). How does leverage affect R\&D intensity and how does R\&D intensity impact on firm value in South Korea? Applied Economics, 48(58), 5667-5675. https://doi.org/ 10.1080/00036846.2016.1181836

28. Motohashi, K. (2005). Firm level analysis of information network use and productivity in Japan. Retrieved from https://core.ac.uk/ download/pdf/7165278.pdf

29. Nagaoka, S. (2006). R\&D and market value of Japanese firms in the 1990s. Journal of the Japanese and International Economies, 20(2), 155-176. https://doi.org/10.1016/j. jjie.2005.07.001

30. OECD. (2008). Intellectual Assets and Value Creation: Synthesis Report. Retrieved from https:// www.oecd.org/sti/inno/40637101. pdf

31. OECD. (2011). New sources of growth: intangible assets. Washington DC: OECD. Retrieved from https://www.oecd.org/sti/ inno/46349020.pdf

32. Osinski, M., Selig, P. M., Matos, F., \& Roman, D. J. (2017). Methods of evaluation of intangible assets and intellectual capital. Journal of Intellectual Capital, 18(3), 470-485. https://doi.org/10.1108/JIC-122016-013

33. Pal, K., \& Soriya, S. (2012). IC performance of Indian pharmaceutical and textile industry. Journal of Intellectual Capital. https://doi. org/10.1108/14691931211196240

34. Pastor, D., Glova, J., Liptak, F., \& Kovac, V. (2017). Intangibles and methods for their valuation in financial terms: Literature review. Intangible Capital, 13(2), 387-410. http://dx.doi.org/10.3926/ic.752

35. Porter, M. E. (1991). Towards a dynamic theory of strategy. Strategic Management Journal, 12(S2), 95-117. https://doi. org/10.1002/smj.4250121008

36. Ramirez, P. G., \& Hachiya, T. (2006). Measuring firm-specific organizational capital and its impact on value and productivity: Evidence from Japan. Review of Pacific Basin Financial Markets and Policies, 9(04), 549574. https://doi.org/10.1142/ S0219091506000860

37. Rao, J., Yu, Y., \& Cao, Y. (2013). The effect that R\&D has on company performance: comparative analysis based on listed companies of technique intensive industry in China and Japan. International Journal of Education and Research, 1(4), 1-8. Retrieved from https://www.ijern. com/images/April-2013/40.pdf

38. Reilly, R. F., \& Schweis, R. P. (1999). Valuing intangible assets. New York: McGraw-Hill.

39. Ruiwen, Z., \& Honghui, G. (2010). An Empirical Test of the Impact of Intangible Assets on Enterprise Performance of Chinese Social Services Listed Companies. In Proceedings of the 7th International Conference on Innovation \& Management (pp. 1373-1377).

40. Sadowski, D., \& Ludewig, O. (2003). Organisational capital: The power of an economic metaphor; organisational capital in German establishments (No. 2003/02). IAAEG Discussion Paper Series. Retrieved from https://www.econstor.eu/handle/10419/51412

41. Salamudin, N., Bakar, R., Ibrahim, M. K., \& Hassan, F. H. (2010). Intangible assets valuation in the Malaysian capital market. Journal of Intellectual Capital. https://doi. org/10.1108/14691931011064608

42. Samuelson, P. A. (1947) Foundations of economic analysis. Cambridge: Harvard University Press.

43. Shah, S. Z. A., Mirza, H. H., \& Abbas, Q. (2011). Advertising Effects on Firm Performance. In Proceedings of the 3 rd SAICON: International Conference on Management, Business Ethics and Economics, SAICON. Retrieved from https://www.academia edu/37841003/Advertising_Effects_on_Firm_Performance

44. Su, W. H., \& Wells, P. (2015). The association of identifiable 
intangible assets acquired and recognized in business acquisitions with postacquisition firm performance. Accounting \& Finance, 55(4), 1171-1199. https:// doi.org/10.1111/acfi.12086

45. Sveiby, K. E. (2010). Methods for measuring intangible assets. Retrieved from https://www.sveiby. com/files/pdf/intangiblemethods. pdf.

46. Villalonga, B. (2004). Intangible resources, Tobin's $\mathrm{Q}$, and sustainability of performance differences. Journal of Economic Behavior \& Organization, 54(2), 205-230. https://doi.org/10.1016/j. jebo.2003.07.001
47. Vithessonthi, C., \& Racela, O. C. (2016). Short-and long-run effects of internationalization and R\&D intensity on firm performance. Journal of Multinational Financial Management, 34, 28-45. http:// dx.doi.org/10.1016/j.mulfin.2015.12.001

48. Wang, M. (2011). Measuring intellectual capital and its effect on financial performance: Evidence from the capital market in Taiwan. Frontiers of Business Research in China, 5(2), 243-265. Retrieved from http://journal.hep.com.cn/fbr/ EN/10.1007/s11782-011-0130-7

49. Wernerfelt, B. (1984). A resourcebased view of the firm. Strategic
Management Journal, 5(2), 171180 .

50. Widiantoro, D. M. (2012). Measuring the Impact of Intangible Asset Investment toward Company Financial Health and Company Agency Problem: Empirical Research from Indonesian Companies during World Economic Financial Crisis 2006-2011. Journal of Finance and Risk Perspectives, 1(2).

51. Yamaguchi, T. (2014). Intangible asset valuation model using panel data. Asia-Pacific Financial Markets, 21(2), 175-191. https:// doi.org/10.1007/s10690-0149181-z 